\title{
Redactioneel
}

\section{De praktische kanten van beslag, beklag en het professioneel verschoningsrecht}

Mr. dr. J.S. Nan*

Als het gaat om het professionele verschoningsrecht in het kader van beslag en beklag, zijn er twee belangrijke figuren. De eerste is natuurlijk de professioneel verschoningsgerechte zelf. Het is diens oordeel dat leidend is bij de vraag of een stuk of een gegeven onder het verschoningsrecht valt, zodat het beslag geen doorgang kan vinden. Bekend is natuurlijk wel dat hiervan wettelijk zijn uitgezonderd de stukken die voorwerp van het strafbare feit uitmaken of tot het begaan van het strafbare feit hebben gediend. Het standpunt van de professioneel verschoningsgerechtigde moet volgens de Hoge Raad worden geëerbiedigd, tenzij redelijkerwijze geen twijfel erover kan bestaan dat diens standpunt onjuist is. Vaste rechtspraak is ook dat het verschoningsrecht niet absoluut is. Er laten zich zeer uitzonderlijke omstandigheden denken waarin het belang dat de waarheid aan het licht komt - ook ten aanzien van datgene waarvan de wetenschap aan de tot verschoning bevoegde persoon als zodanig is toevertrouwd - moet prevaleren boven het verschoningsrecht.

En dat brengt ons bij de tweede centrale figuur: de rechter-commissaris. Het is de rechter-commissaris die in eerste instantie moet beoordelen of het standpunt van de professioneel verschoningsgerechtigde juist is of niet en of zich eventueel zeer uitzonderlijke omstandigheden voordoen. De rechter-commissaris behoort daarbij als het even kan overleg te hebben met een gezaghebbend vertegenwoordiger van de beroepsgroep van de professioneel verschoningsgerechtigde (bij advocaten de (plaatselijke) deken). Duidelijk is ook dat de rechtercommissaris kennis mag nemen van de stukken voor

* Mr. dr. J.S. Nan is advocaat-partner bij Wladimiroff Advocaten te Den Haag. zover dat noodzakelijk is om tot een afgewogen oordeel te komen.

De persoon op wie de stukken betrekking hebben (de cliënt, patiënt, etc.) heeft in dezen geen stem, althans geen doorslaggevende. Hij is dus - gek genoeg - geen centrale figuur. Hij dient uiteindelijk het oordeel van de professioneel verschoningsgerechtigde en daarna eventueel het oordeel van de rechter-commissaris af te wachten. Een beklag van de betrokkene tegen de beslissing van laatstgenoemde dat kennis mag worden genomen van de stukken, hangt qua uitkomst samen met de uitkomst van het beklag van de professioneel verschoningsgerechtigde - als dat wordt ingediend. Datzelfde geldt voor de afgeleid verschoningsgerechtigde. Diens verschoningsrecht is afhankelijk van de uitoefening van het verschoningsrecht waarvan het is afgeleid.

Als een klaagschrift wordt ingediend tegen de beslissing van de rechter-commissaris om de inbeslagneming toe te staan, mag de raadkamer van de rechtbank, net als de rechter-commissaris, zo nodig kennisnemen van de betreffende stukken. Het kan voor de rechtbank anders lastig zijn om te beoordelen of de rechter-commissaris tot diens oordeel heeft kunnen komen.

Bij deze beschrijving van de te volgen procedure, is het steeds een rechter geweest die, indien noodzakelijk, kennis mocht nemen van de stukken. De Hoge Raad had ook bepaald dat het kan zijn dat bijvoorbeeld de aard en de omvang van de in beslag genomen stukken of gegevens, maken dat de rechter-commissaris het onderzoek ter schifting niet zelf kan verrichten. De rechter-commissaris zal het dan daarheen dienen te leiden dat dit onderzoek wordt verricht door zodanige functionaris en op zodanige wijze dat is gewaarborgd dat het 
verschoningsrecht niet in het gedrang komt. Maar wat houdt dat in?

In en uit de zaak HR 16 juni 2020, ECLI:NL:HR: 2020:1048 wordt meer duidelijk. Het ging in die zaak om een beslag op gegevensdragers met meer dan twee miljoen bestanden. Het beslag was gelegd onder de verdachte directeur van een bedrijf dat internationaal ambulancevervoer verzorgt, die zich daarover beklaagde. De algemene overwegingen van de Hoge Raad zijn als volgt. Als het gaat om een beslag met heel veel stukken of gegevens, ligt het volgens de Hoge Raad 'doorgaans in de rede dat onder leiding van de rechter-commissaris een schifting wordt gemaakt tussen stukken of gegevens die wel en die niet onder het verschoningsrecht kunnen vallen'. Dat kan bijvoorbeeld door gebruik te maken van een lijst met relevante zoektermen (zoals namen en e-mailadressen of termen die specifiek kunnen duiden op het voorwerp van het ingeroepen verschoningsrecht). De Hoge Raad benadrukt nogmaals dat de rechter-commissaris het onderzoek zo dient in te richten 'dat voldoende wordt gewaarborgd dat het verschoningsrecht niet door het strafrechtelijk onderzoek kan worden geschonden.' Daarom kan het zo zijn dat bij de inrichting van de schifting aan de hand van zoektermen, zowel de afgeleid verschoningsgerechtigde als een gezaghebbend lid van de beroepsgroep van de verschoningsgerechtigde dan wel een andere ter zake deskundige persoon bij de voorbereiding en uitvoering van dit onderzoek wordt betrokken.

$\mathrm{Na}$ de selectie kan de rechter-commissaris beslissen dat het beslag op de overgebleven stukken of gegevens kan worden toegestaan, omdat het niet gaat om onder het verschoningsrecht vallend materiaal. Maar dit kan in beginsel niet voordat de afgeleid verschoningsgerechtigde 'in de gelegenheid gesteld [is] zich uit te laten over de toelaatbaarheid van het gebruik van de voorgeselecteerde stukken of gegevens voor strafrechtelijk onderzoek'. Vervolgens moet de rechter-commissaris de personen met bevoegdheid tot verschoning mededelen dat tegen die beslissing beklag openstaat, alsmede dat van de stukken geen kennis wordt genomen dan nadat onherroepelijk op het beklag is beslist (vlg. art. 98 lid $3 \mathrm{~Sv}$ ). Die mededeling is evenwel niet nodig als 'het redelijkerwijs als gevolg van de omstandigheid dat de stukken of gegevens in relatie lijken te staan tot (vele) verschillende onbekende of niet eenvoudig te achterhalen geheimhouders niet mogelijk is gebleken alle (eventuele) verschoningsgerechtigden in staat te stellen zich uit te laten over hun verschoningsrecht met betrekking tot de geselecteerde stukken of gegevens'. Maar dienaangaande moet de rechter-commissaris wel de nodige inspanningen hebben verricht, aldus de Hoge Raad. Hij mag zich er dus niet met een jantje-van-leiden van afmaken (daarvoor zijn de belangen inderdaad ook te groot, zou ik zeggen). Daarbij geldt volgens de Hoge Raad dat de rechter-commissaris er zeker van moet zijn dat het niet aannemelijk is dat er (nog) een verschoningsgerechtigde is die zich met betrekking tot na de schifting overgeble- ven stukken en gegevens op zijn verschoningsrecht beroept.

In de zaak van 16 juni 2020 heeft de Hoge Raad geaccordeerd dat zogeheten geheimhouders-politieambtenaren en geheimhouders-officieren van justitie zich met de selectie van de stukken/gegevens die wel of niet onder het professioneel verschoningsrecht vallen, bezighouden. Onder regie van de rechter-commissaris was in overleg met de directeur als afgeleid verschoningsgerechtigde, via geheimhouders-politieambtenaren, die onder toezicht van een geheimhouders-officier van justitie werkten, een selectie gemaakt van de gegevens welke wel en niet onder het afgeleid verschoningsrecht vielen. Daarbij heeft de raadsman van de directeur van de internationale ambulancevervoerder inspraak gehad in de uitgebreide zoektermen ter filtering (welke zoektermen ook in diverse andere talen zijn gebruikt). De selectie had niet alleen betrekking op tekst (in e-mails), maar ook op afbeeldingen en audio- en videobestanden.

Die werkwijze kon de goedkeuring van de Hoge Raad wegdragen, ook omdat van de zijde van de klager uiteindelijk alleen nog werd gesteld dat "“zich tussen de uitgeselecteerde informatie nog steeds medische gegevens bevinden", zonder voldoende nadere toelichting over gronden waarop aangenomen zou moeten worden dat het aannemelijk is dat er een verschoningsgerechtigde is die zich met betrekking tot na de schifting overgebleven stukken en gegevens op zijn verschoningsrecht beroept'. De afgeleid verschoningsgerechtigde zal zich dus inspanningen moeten blijven getroosten om redelijk concreet potentiële geheimhouderstukken aan te wijzen.

De praktische uitkomst van deze zaak dat volgens alle rechters het afgeleid verschoningsrecht voldoende is gewaarborgd, verbaast op zich niet. Wel is het zo dat ik minder gelukkig ben met het feit dat in deze werkwijze ook politieambtenaren en officieren van justitie betrokken kunnen zijn, ook al zouden zij losstaan van het strafrechtelijke onderzoek. Op praktische gronden is het logisch dat zij de selectie uitvoeren, omdat zij, anders dan het gemiddelde kabinet rechter-commissaris, goed geëquipeerd zijn om grote hoeveelheden bestanden te filteren. Fundamenteel bezien lijkt het me echter onjuist dat personen van de opsporingsdiensten de selectie uitvoeren, ondanks het feit dat zij niet bij het concrete strafrechtelijke onderzoek betrokken zijn. De rechterlijke magistratelijkheid is een andere dan de magistratelijkheid van de officier van justitie. En politieambtenaren zijn wel professionals, maar in het geheel geen magistraten. Om alle schijn en misstanden te voorkomen is het zuiverder dat een andere oplossing wordt gekozen als de rechter-commissaris en diens kabinet de filtering gezien de aard of omvang niet aankunnen. Kan niet één landelijk (super)kabinet worden gevormd om dit soort beslagperikelen af te wikkelen?

Het lijkt me in ieder geval dat bij de selectie van de stukken of gegevens, de geheimhouders-functionaris geen kennis behoort te (kunnen) nemen van de inhoud 
daarvan. Bij twijfel zal het hooguit de rechter-commissaris mogen zijn die de stukken inhoudelijk mag en kan beoordelen (en bij onenigheid vervolgens de raadkamer). Alleen dan wordt gewaarborgd dat het verschoningsrecht niet door 'het' strafrechtelijk onderzoek kan worden geschonden. En dat vindt ook de Hoge Raad nog steeds belangrijk. 